Article

\title{
Different Uses of Ozone: Environmental and Corporate Sustainability. Literature Review and Case Study
}

\author{
Marco Remondino ${ }^{1, *(1)}$ and Luigi Valdenassi ${ }^{2}$ \\ 1 Department of Economics (DIEC), University of Genoa, 16126 Genova, Italy \\ 2 Department of Internal Medicine and Medical Therapy, University of Pavia, 27100 Pavia PV, Italy; \\ luigi.valdenassi@unipv.it \\ * Correspondence: marco.remondino@economia.unige.it; Tel.: +39-346-217-4311
}

Received: 28 October 2018; Accepted: 11 December 2018; Published: 14 December 2018

check for updates

\begin{abstract}
An extensive and interdisciplinary literature review was carried out to evaluate the uses of synthetically produced ozone in many different application areas. The objective of the study was to investigate the disinfectant and purifying effectiveness of this natural compound and evaluate its use as an economically and environmentally sustainable alternative to treatments that often involve the adoption of pharmaceutical agents. Being a natural substance, the potential environmental sustainability of the use of ozone in areas such as water disinfectant; pesticide action in agriculture; and antibiotic, anti-inflammatory and antiviral actions in animal husbandry and fish farming are of interest. In addition to environmental sustainability, economic sustainability is also important for companies employing ozone in their processes. Thus, a case study was proposed that represents the use of ozone in a pilot swine farm located in Northern Italy, both as an alternative to pharmaceutical drugs for the animals and as an air and water purifier. The case study demonstrates the economic sustainability of ozone use, especially in the medium run, along with its ability to reduce animal mortality (by about $2 \%$ ), as well as decrease use of pharmaceutical antibiotics.
\end{abstract}

Keywords: ozone; water treatment; agriculture; animal husbandry; literature review; environmental sustainability; economic sustainability; managerial evaluation

\section{Introduction}

Increasingly, companies and, more generally, organizations are pursuing economically, environmentally and socially sustainable development. This trend often leads to reengineering policies and business strategies [1-3]. Sustainability policies involve different areas, develop new values and make it necessary to develop new strategies and practices to achieve these specific goals. These strategies can play a significant role in many areas of business management. For example, in the context of production, a reduction in environmental impact is usually required, as well as an increase in worker safety and product quality. In the context of marketing, communication strategies place the emphasis on green economy, organic and natural products and reduced use of pollutants. In the area of human resource management, social sustainability involves keen career management and evolved employee training.

From an entrepreneurial point of view, the paradigm of creating economic value for stakeholders is accompanied by the search for a balance between environmental impact, conscious management of resources (including human resources) and the achievement of economic results.

Thus, a strategy oriented towards sustainability requires an overall attitude on the part of corporate governance, which also involves the selection of potentially innovative procedures that 
place the safeguarding of life at the center of production activities [4,5]. Sustainability requires interdisciplinary green chemistry principles to achieve innovative techniques [6]. It is therefore clear that, for sustainable development, a propensity to change is necessary [7], even when this involves the use of practices completely different from those used for a long time.

This is where ozone comes into play: ozone is a triatomic inorganic molecule [8], made up of three atoms of oxygen. It is a highly unstable matter that, under specific conditions, such as pressure and temperature, splits into oxygen atoms with a short life span, which is why after a certain period of time it will decay into its original form [9].

It is synthetized in three different ways [10-13]: by electrical discharges of 10-15,000 volts that break the oxygen molecule, and form an atom of the same, which binds to $\mathrm{O}_{2}$ forming $\mathrm{O}_{3}$; through ultraviolet radiation; and by some chemical processes.

The word ozone, from the Greek "ozein" [14], was first used in 1840 by the chemist C. F. Schonbein $[15,16]$, a professor at the University of Basel who sensed that, by subjecting oxygen to electric shock, a strange smell was emitted into the air, due to the presence of a gas called ozone. Since then, numerous researchers $[17,18]$ have pursued to clarify the origin, actions and molecular structure of ozone, demonstrating that it is an allotropic form of oxygen. The main properties of ozone are due to its oxidizing power. Through its application, it is able to break down macromolecular compounds constituting the integrity of bacteria, protozoa, viruses and fungi.

For this reason, it is used in various fields of medicine [9,19], particularly as a substitute for antibiotics $[20,21]$ and pharmaceuticals, against which bacteria have developed in recent years a resistance [22-24], often due to over usage of the drugs themselves. The use of ozone in this sector, known as ozone-therapy, has been taking place for a century now as a medical approach, and has spread and developed in some European and South American regions, unlike other countries where it has not been received as expected [25].

Ozone properties also have positive effects in the agricultural sector: in the cultivation and production of plants to replace chemical and pharmaceutical products; in the food, industrial, textile and paper sectors; and in the disinfection of water [26,27], both for drinking water [28,29] and in the processing of waste water [28,30-32].

The application of ozone to water is carried out in place of other disinfectants [33,34], providing, unlike the latter, a safe sanitization that does not involve any release of chemical residues, such as chlorine, which in recent years has been replaced by ozone in swimming pools, spas and in many other areas that require clean and safe water. It also does not alter the characteristics of water, especially the taste, and generates fewer harmful by-products.

After some encouraging pilot tests carried out in 1891, in Martinikenf, Germany, in 1893, the first ozone-based drinking water treatment prototype plant was built in Oudshoorn, Netherlands. After decantation and filtration, the water of the River Rhine was purified with ozone. Some French scientist, chemists and doctors examined this apparatus and decided to build their own plant, in Nice, France, in 1906. Since ozone has been constantly and regularly employed in Nice since then, it is often referred to as the cradle of ozone treatment of drinking water [29].

In these same years, other plants for the purification of drinking water appeared in Germany (Wiesbaden) [35] and then later in Zurich, Brussels, Marseille, Singapore, Moscow and some large Italian cities including Turin, Florence, Bologna and Ferrara, which ozonate water taken from rivers to provide drinking water.

Ozone, therefore, has proven to be a great opportunity for the environment [36]: it is considered an excellent ecological disinfectant because it has no negative impact on the environment. Considering that it is a natural molecule, it effectively reduces the consumption of chemicals, does not create harmful by-products and is absolutely ecological and economical, as it helps to reduce the need for repeated purchase of pharmaceutical drugs, dosing costs, steering rates and storage and management.

In the following, first some properties and uses of ozone are listed and analyzed; in particular, the disinfectant and antibacterial capacities are emphasized. Subsequently, a specific case study is 
presented, in the field of animal husbandry, to better understand how ozone can be considered a source of sustainability, from both the environmental and the economic and financial points of view, for an enterprise deciding to use it as an alternative to more traditional techniques.

The novelty of the study lies in the fact that it performed an interdisciplinary investigation, spanning from the economical/financial aspects to the environmental ones, on the use of ozone in different fields, supported by a cross-disciplinary literature review and a specific case study. In particular, managerial insights are given, derived from the proposed case study.

\section{Ozone in General Disinfection and Water Treatment}

Ozone is considered as a broad spectrum anti-microbial agent [37] and one of the most powerful natural germicidal and purifier substances [38], endowed with antibacterial properties [21], while preserving the integrity of foods and water when used correctly $[39,40]$.

The most common industrial uses of ozone concern disinfection [41], a field where it has an important role in drinking water and wastewater clarification; sanitizing of areas, devices and appliances; conservation of edible materials; agriculture and ranching; removal of alchemical hazards; sanitation of natatoriums; bath tubs; and mussel and fish farming [42-44].

The application of ozone in water disinfection allows the removal of bacteria and viruses, while not introducing any mutation of odor and taste and not leaving any residues; it is active also at ambient temperatures $[33,34]$.

Several researchers have recognized the relevance of moisture in the hygienic activity of ozone [21,45-47], and specific trials have shown that microbes are almost unaffected when exposed in dry settings. The most powerful action is accomplished in presence of water or moisture [48].

Temperature is another factor that affects the germicidal effect, as low temperature raise the sterilizing action because the amount of gas dissolved in the liquid increases [49].

Different bacteria show variable sensitivity to ozone; Gram-negative bacteria are less sensitive than Gram-positive ones; and sporygenic bacteria are more resistant than non-sporygenic ones [50,51].

However, this different sensitivity is to be understood in a relative sense, because ozone is considered an excellent water disinfectant and sterilizer. Hence, it has been regularly applied for many years in water purification networks [34].

Ozone is becoming a popular disinfectant for drinking water in several countries [52], both for its proven efficacy in destroying germs, and because it does not leave derivatives and residuals of any kind.

Numerous organic and inorganic drinking water disinfection byproducts (BDPs) $[53,54]$ have been identified, consisting of ozone and its combination with chlorine or chloramine [53].

Ozone, thanks to its oxidizing power, guarantees the disinfection and sanitization of tanks and cisterns, eliminating viruses, bacteria, algae, fungi and molds.

The sanitization of tanks [55] is particularly important to provide the hygiene of water and the application of ozone therefore allows to destroying the microorganisms and algae that often originate within them [56].

Therefore, ozone allows improving the hygiene of waters in an economic and effective way and inhibits the transmission of bacterial and viral infections.

With appropriate treatments of tanks and pipes, it is possible to control the problem of legionella $[57,58]$, which is one of the etiological agents of bacterial pneumonia mainly associated with the presence of standing water and can eventually colonize the water networks, acting as amplifiers and disseminators of the microorganism [59].

In water systems, legionella can be found in both free form and anchored to biofilm, i.e., to a film of microorganisms immersed in an organic matrix, which provides sustenance and shelter to the bacterium [60].

For years, ozone has also been successfully used by many companies in the processing and packaging of fish products [61,62]. 
Ozone can be used effectively in the industrial phases of washing and processing of fish [63] (in this phase, ozone-conditioned water can be used both to reduce odors and to disinfect the fish, increasing its shelf-life by several days, reducing the formation of ammonia resulting from the processes of putrefaction and avoiding leaving residues such as chlorine) in the purification phases of filtered fish products (e.g., mussels, clams, tellins, etc.); in the steps that follow their collection, but precede the final stages of pre-commercial packaging; and in the washing and external grooming phases before their final introduction into the commercial circuit.

The use of ozonated water for CIP (Clean-in-Place) [37] allows replacing the rinsing phase of surfactants, disinfection with chemical and pharmaceutical products and consequent rinsing with a single treatment with ozonated water. This means huge cost savings for companies in terms of chemicals and cleaning personnel.

Ozone can also be used to treat irrigation water [64-66], as its disinfectant effect can be used in the fight against parasites and harmful insects, against bacterial and fungal infections in outdoor vegetable crops or in greenhouses for human and animal food use, all without the use of chemical, pharmaceutical or synthetic products such as hydrogen peroxide, chlorine derivatives, ammonium derivatives, peracetic acid, fungicides, and so forth.

The beneficial effect of ozone in irrigation water also extends to the quality of the crops themselves, as discussed below: plant products, stimulated in the lymphatic channels by ozen, increase the process of photosynthesis and therefore visibly the aesthetic and dimensional value with an effect of greater lushness and greater yield per square meter.

Since ozone does not release any residue, the soil, groundwater and irrigation channels receive pure water without any risk of pollution.

Ozone has a very high oxidizing potential; is an ecological treatment; and is fast and effective, with its effectiveness being far greater than the affiliated products or treatments, thus its use is widespread worldwide.

Ozone is also used in swimming pools, spas and whirlpools [67,68]; being an effective disinfectant, it leaves no residue and, when used in the right quantity, it has therapeutic effects (improvement of respiratory function [69], muscle and nerve relaxation [70], improvement of blood oxygenation [71,72] and improvement of circulatory activity [9,71,73]); does not irritate the skin [74], eyes, or nostrils; avoids the use of chemicals; contributes to water saving; and provides clean, crystal clear water from the source through a process of water clarification, a process known and pursued by many European countries and Canada [32].

This application is often split into two stages: an initial one, of preliminary ozonation, succeeded by the separation, in suspension, of substances $[75,76]$ and subsequent filtering with the purpose of eradicating all those elements that the oxidizing properties of the ozone cannot destroy. The subsequent stage, referred to as "secondary ozonation", has a longer duration and is aimed at eradicating pathogenic microorganisms. It is then followed by filtering by activated carbon, able to obstruct hazardous contaminants.

Many studies have shown that ozone can be as effective as chlorine [77], which is a standard method in disinfection of swimming pools and aquariums. Only a few years after numerous studies had been carried out, it was realized that the effect of chlorine was beginning to lose its effectiveness and that the bacteria and diseases present in the water were resistant to the substance $[78,79]$. This phenomenon of chlorine bacteria resistance has become increasingly frequent, posing a real threat to public health. The proposed solution to at least part of the problem is to use secondary disinfection systems, such as ozone.

This is the reason ozone is also employed in the sanitation of pools, natatoriums, tubs and in various water systems, where in addition to eliminating some viruses present in the water, it generates potential redeeming of chlorine (estimated $80 \%$ ), a minimization in the reintegration of water. Besides, the system can be totally automated, hence not requiring specific and trained personnel [80]. 
Moreover, ozone allows eliminating, by oxidation, some substances from drinking water, such as iron, manganese, trihalomethanes, phenols, and various organic compounds, that disturb the correct use of water or are harmful to health $[28,81]$.

\section{Antibacterial Properties}

Ozone can play a role in the medical $[82,83]$ as well as other fields because of its antibacterial properties and the continuing spread of the antibiotic-resistance phenomenon [22,78,79], i.e., the inability of antibiotics to effectively combat infections and bacteria, a phenomenon determined by excessive and often inappropriate use of antibiotics for both humans and animals.

Ozone could be a partial solution to aid the pharmaceutical industry, which has not been able to provide necessary countermeasures in terms of advanced research in the short term [84].

In a recent research [85], the World Health Organization (WHO) calculated that there are already hundreds of thousands people who suffer from antibiotic-resistant infections and many people are in serious danger.

In Italy, the resistance of Klebsiella (a bacterium) to carbapenems (a class of antibiotics) suddenly increased in 2010. At present, it appears to be stable at a level of about 30\%. The most dangerous situation is associated with Escherichia coli, with a percentage of methicillin-resistance of more than $30 \%[84,86]$.

Resistance to drugs is, therefore, a serious problem, considering that, in Italy alone, there are 7000 victims of bacterial infections contracted in hospitals that the antibiotics themselves cannot cure; 700,000 deaths occur per year and if no effective action is introduced it will increase to 10 million deaths in 2050 [87]. This involves not only a public health problem but also a problem for the development of global progress [88].

The main cause of antibiotic resistance is the $m c r-1$ gene, first identified by Chinese researchers in November 2015 [89,90], which puts bacteria in a position to resist the most potent chemical and pharmaceutical drugs [86].

The consequences of antibiotic resistance threaten all health systems, not only human and animal health but also economic and social development [88,91].

Antimicrobial efficacy must be seen as global welfare. It is a resource that can become scarce as the efficacy decreases. For this reason, there is a concept of "collective responsibility" to defend and perpetuate it [91].

Bacterial resistance to antibiotics depends on several factors, and primarily the structural change of the surface envelopes of the bacterial cell, which reduces the penetration of the antibiotic. In Gram-negative bacteria, resistance may be due to alterations in the protein membrane through which many antibiotics penetrate.

In other cases, the bacterium manages to expel the drug, which has already entered the cell, thanks to outflow pumps that operate coupled with a particular type of protein. It can also happen that the target of the antibiotic is modified and therefore no longer identified by the drug or that the antibiotic loses its biological activity because it is inactivated by some specific enzymes produced by both Gram-positive and -negative bacteria.

Faced with what could become a global emergency in the next few years, two solutions are possible: to continue to invest in the production of increasingly effective antibiotics, which is a very resource-intensive solution and potentially not sustainable in the long run, or to encourage the application of alternative therapies that can be used alongside chemical/pharmaceutical drugs [92-94]. One of these alternatives seems to be ozone therapy.

As already pointed out, ozone has an oxidizing ability that can kill some bacteria by attacking the molecular structure of their protective membranes and altering the internal enzymes $[40,95,96]$. This mechanism is very similar to the one used by white blood cells during bacterial phagocytosis [97].

It is also extremely effective against viruses, fungi, molds, pesticides, heavy metals, nitrates, nitrites and other potentially harmful substances [98]. 
No bacteria, viruses or fungi can withstand a proper dose of ozone administered at the right time [84].

As reported in the medical-scientific journal "Ozone Therapy", 5.7\% of all types of Klebsiella pneumoniae isolated in Europe in 2014 were resistant to all groups of antimicrobial agents normally used. In addition, more than $80 \%$ of these were reported in Greece and Italy [86].

Ozone has been used as an antibacterial agent in various forms such as ozonated salt solution, ozonated water, ozone associated with particular oils or other types of substances, and, more frequently, the gaseous mixture of oxygen and ozone.

In addition, several studies indicate that the sensitivity of microorganisms to antibiotics increases when using ozone, as does the effectiveness of the immune system [99].

Ozone can hence be used in combination with antibiotics from the very beginning of the treatment, thus enhancing the effectiveness of the treatment [100].

In veterinary medicine, the utilization of ozone aims to enhance the immune system of animals, by lowering the microbial load [62].

\section{Ozone in Agriculture}

Other sectors can also benefit from the properties of ozone. One of these is the agricultural sector, which uses numerous chemical and pharmaceutical products in the production and cultivation of plants, that, sometimes, could have negative effects on people [101,102] and the surrounding environment, potentially even causing poisoning [103], chronic diseases and a decline in ecological quality [104-106] since, after their use, residues are released to the ground and, through it, to water and within the vegetables themselves, thus creating permanent damage.

The solution proposed as an alternative to the traditional approach is ozone [107] that, when used in the agricultural industry and in different technological processes, has already proved very effective for its disinfectant power, as mentioned in the previous section, for its biocidal properties and for the ability to induce in plants the activation of biochemical processes associated with the response of resistance to phytopathogenic microorganisms [108].

Ozone, in fact, can be effectively used in agriculture, both soiled and soilless and in aboveground agricultural rainwater harvesting systems, seed production, seedling production, greenhouse floriculture, wet rooms, mushroom cultivation and irrigation to eliminate bacteria and microorganisms that can damage plants from germination, and in post-harvest storage to enhance the quality of products.

Thanks to its disinfectant power, ozone is used to counteract and destroy parasites, as in the case of nematodes [109], microscopic worms transported from the soil that deposit parasites on the roots of plants, consume sources of nourishment present in the fibers of the plant, cause cells to break and proliferate out of control, creating, at the nodes of the roots, malformations that conflict with the physiological flow of water and, hence, of minerals and nutrients, thus incrementing the sensitivity of plants to disease. The deterioration caused by the disease of the nutritional system of the plant is often exteriorized by skimmed growth and yellow leaves, along with low abundance of fruits.

In this case, ozone could be applied through direct irrigation of the soil with ozonated water or through gas fumigation; in this way, it would bring benefits to the surrounding environment following the elimination of residues present in nature and economic savings, since its primary material is oxygen [110].

A specific use case, in agriculture, which demonstrates the validity and effectiveness of ozone with respect to pesticides is the cultivation of strawberries, a very precious and loved fruit, but at the same time very sensitive to several fungal diseases and pests, which involve a significant use of pesticides, fungicides and insecticides [48].

Pesticides act in various ways and flow differently, when reaching the plant. Frequently, through a systemic activity, they penetrate through foliage, peduncles, branches and roots. By means of plants' 
internal transport systems, which are highly specialized tissues, they move inside the plant reaching every part of it and, eventually, the fruits intended for consumption by humans and animals.

The excessive use of pesticides, despite being used to eliminate parasites on plants, could potentially cause damage to the environment as well as to humans and animals, due to residues that are released in excessive quantities on the plant [111].

This creates the need to reduce the use of pesticides and insecticides present on strawberries through the study of certain methods and support equipment.

The use of ozonated water, possibly backed by boiling and ultrasonic waves, has proved to be a very effective solution, resulting in savings in economic terms for farms with the consequent increase in productivity and the possibility of producing healthier products, since ozone, unlike most chemicals and drugs used for disinfection and purification, leaves no trace on the products [112].

Ozone, used as a substitute for chemical/pharmaceutical products, does not leave any residue and increases the amount of oxygen in the soil and water, which provides the right conditions for healthy soil and healthy plant growth, thus is a fast, effective and economical practice; is environmentally friendly; and results in the reduction of antibiotic and disinfectant treatments.

Ozone is also suitable for the ablution and purification of agricultural products, machinery, edible material, contact surfaces and, when used in combination with appropriate initiators, is efficient towards germs and microorganisms [113].

Ozone can also be used to enhance and recycle water in vegetables washing and processing processes, thus significantly reducing overall water consumption, while at the same time enabling the transfer of the best water resources to more appropriate uses. This is the case with one of the largest producers of caramel apples in the United States, which, to improve the quality of apples for its consumers, decided to use ozonated water instead of chlorinated water to treat apples, thus achieving a saving of saving more than 12,000 gal/week (45,000 L/week) and a considerable reduction of bacterial agents in the water [114].

Therefore, the use of ozone in agriculture improves and positively disrupts the life cycle of plants, in a sustainable way, bringing about increases in photosynthesis of chlorophyll, vegetative recovery, greater resistance of the plants themselves and a qualitatively and quantitatively higher production.

\section{The Use of Ozone in Animal Husbandry and Fish Farming}

Moving away from the agricultural sector, also the livestock and animal husbandry sectors benefit from the use of ozone [115-119]. In this case, ozone can be an effective aid in the breeding of dairy cattle, beef cattle, sheep, pigs and rabbits [84].

As already noted, ozone can, with appropriate dosing and proportioning, destroy even the most resistant bacteria [46,85], causing their death by oxidative lysis of the plasma membrane within 4.5 min and, similarly, the same principle can be applied in cells, where viruses, failing to replicate, are inactivated $[98,120]$.

Most farms have the same problems with environmental conditions, which facilitate the transmission and spread of diseases by air such as fowl cholera (Pasteurella multocida), Avipoxvirus, Salmonella, avian influenza, infectious bronchitis, Staphylococcus infection and so on [121]; lack of oxygen due to poor ventilation and overcrowding of animals; strong exhalations of ammonia gas, hydrogen sulfide, carbon dioxide, methane, etc.; and bad conditions, which facilitate the transmission and spread of diseases by air [122].

Ozone can be used in livestock farms to lower the microbial load; it can be dissolved in water (0.2-0.5 mg per liter), or dispensed in the environment at a concentration of 0.1/0.2 ppm [84].

The use of ozonated water in animal husbandry $[98,123,124]$ has a number of benefits that result in an improvement of the general health conditions of the animal. Water not being treated could contain a percentage of bacteria, viruses, pesticides and other highly harmful substances, which is why it was decided to use a technology for disinfection of water that can leave no residue. 
Enriching the water of a farm with ozone has advantages for the washing of the stables, for the consumption of animals and for the sanitization of the environment by eliminating the spread of bacteria, protozoa, fungi and viruses and bad smells.

As far as the supply of ozone in the air is concerned, two different methods are used depending on the capacity of the farm. When the husbandry is relatively small, ozone is dispersed in the environment through ozone diffusers; for bigger dimensions, the used tool is a fan for air introduction with which the ozone is injected in the ventilation duct emitting air from outside inside the barn, assuring the entry of purified air, thanks to the action of the ozone [84].

The ozonation of the environment during the incubation of chickens involves a higher level of air purification from microorganisms and dust, resulting in an increase in the percentage of openness and safety [107].

Ozone, therefore, allows a regeneration of the air, increasing oxygenation, the elimination of bacteria and viruses and a decrease in unpleasant odors that contaminate the entire area $[125,126]$.

These benefits also have positive repercussions in the economic sector, leading to a reduction in heating costs in the winter periods following the decrease in the use of ventilation and a reduction in the cost of medication, because the use of ozone, through both water and air, allows improving the health conditions of animals and lowering the percentage of diseases, which are common among livestock; moreover, by using for several days hyper-ozonated water and high concentrations of ozone at the end of the cycle, i.e. when the shed is empty, it is possible to make the environment completely sterile and completely disinfected, free from any kind of outbreak or accumulation of bacteria or viruses [127].

Ozone can be also used in fish farming [128-131], both in incoming water and in recirculation on farms, achieving a marked improvement in the quality of the water itself, by means of [132]:

- $\quad$ Reduction of the load of bacteria, viruses, protozoa and fungi pathogenic to fish;

- Elimination of colloidal substances suspended in the water and removal of dissolved organic substances that can stress the fish;

- $\quad$ Removal of ammonia and nitrites that may be toxic to fish;

- $\quad$ Increased growth rate (faster growth of fish);

- Increase in food conversion factor (food transfer factor), resulting in a decrease in the amount of food to achieve the same percentage increase;

- Greater fish production achievable with the same structures (epidemics caused by a certain pathogen can cause production losses ranging from $20 \%$ to $70 \%$ );

- $\quad$ Fish product obtained at a lower cost and therefore more competitive.

As mentioned above regarding disinfection of water, the use of ozone provides water under hygienic conditions, which are ideal for the development of aquatic animals. When used in correct dosing, it does not damage them, but provides well oxygenated water, free of pathogens and microorganisms. Hence, in fish farming, the results of the application of ozone are very positive; for example, it is possible to reduce enormously the volume of water required per ton of fish produced [95], and to find that fish reared in purified water assimilate much better the feed intended for them, thus the ratio of weight gain as a function of the amount of feed supplied is much more favorable [132], with the obvious economic return that follows.

Ozone can also be employed in the veterinary sector, thanks to its healing, anti-inflammatory and antiseptic properties; it is used in the prevention and treatment of mastitis [133,134]; in the prevention against the spread of epidemics from parasites in livestock farms, as already mentioned, in the poultry industry $[117,135]$, through the treatment of water and air, generating a reduction in mortality and an increase in the weight of animals; in the purification of warehouses for animal feed [95]; in the disinfection of environmental equipment [37]; and in microbiological decontamination.

The ozone oxygen therapy, thanks to its mechanism of action, can be a valid therapeutic support in the course of diseases such as Leishmaniasis, FIP (Feline Infectious Peritonitis), FIV (Feline 
Immunodeficiency Virus) and infections by Herpes Virus [136-138] and being a natural medicine is free of side effects, sustainable in the long run and harmless, generating positive effects in the general state of health of the animals.

\section{A Case Study in Animal Husbandry}

A case study for what has been said and studied thus far, is provided by the analysis of the animal husbandry sector, in the form of a pilot swine farm, located near Brescia, in Northern Italy.

The owner of the pilot farm used for this study became a veterinary surgeon in 1991 and some years later, in 1995, he was awarded the diploma of homeopath at the Hell in Baden-Baden, Germany. In 2001, after practicing for eleven years the profession of veterinary surgeon, he decided to work on his family farm, a swine farm for the production of Parma and San Daniele ham.

Always concerned about the excessive use of antibiotics in medicine and food, he worked to find solutions and potential innovations that could lead to a decline in the use these substances, very common and, in his vision, often abused in the veterinary sector.

As mentioned above, one of the main issues of pig, cattle, sheep and poultry farmers is indeed linked to the excessive consumption of chemical drugs and antibiotics to prevent infections, viruses and diseases that have proved dangerous for the animals.

In the past, very little importance was attributed to the natural defenses of the organism, having, as a sole aim, that of annihilating the pathogen at the root.

Objectively, the pharmaceutical path described above has always proved to be the most straightforward and practical to pursue, but over time has come to create an increasingly explosive threat because the continuous and excessive use of drugs as a remedy for infections and diseases has led to a decline in the effectiveness of the pharmaceuticals themselves, which had the consequence of administering larger and larger doses of the products [84,92]. This is the cause that led to antibiotic resistance and to the spread of increasingly weak and defenseless animals.

As an entrepreneur, the owner of the pilot farm wanted to redefine the objectives of his work, claiming to consider "honest" his economic gain, only if it also includes an adequate effort not to harm the environment and human health, something that he considers impossible to pursue with the continuous use of antibiotics and drugs. In other words, he has pursued sustainability in his business, both economically and environmentally/ecologically.

For this reason, he decided to devote himself to the breeding of pigs using different techniques, until he found some that proved to be both profitable and satisfactory, focusing mainly on strengthening the immune system of its animals.

Today, the swine farm hosts about 7000 pigs, for which different breeding methods have been used in recent years.

Initially, numerous experiments were carried out with homeopathic and phyto-therapeutic products, up to the point of choosing some very good ones that are now used daily.

In late 2013, the farmer learned about ozone therapy, which appeared very interesting to him. Being open to alternative therapies and very fond of natural substances, he decided to test the method directly on its animals. Hence, since the beginning of 2014, the first pioneering oxygen-ozone plant was installed in the farm and put into use.

The costs incurred for the purchase of the ozone plant were about $€ 90,000$, while the current maintenance costs, vary within $€ 5000-6500$ per year, including about $€ 4000$ of electrical costs, concerning the consumption of electrical energy used to generate ozone. Considering the initial cost of the plant, a $€ 9000$ per year depreciation was also considered.

Ozone is supplied to both water and air; in the first case, the concentration of ozone is $0.2-0.5 \mathrm{mg} / \mathrm{L}$. Introduced in the intestine, ozone restores a suitable eubiosis by reducing the importance of pre/probiotic additions or enhancing them (synergistic effect). Pathogenic germs do not find room to carry out their disturbing and/or pathogenic action. The analyses on animals are made through 
laboratory data. In particular, alterations of alpha-amylases and transaminases, fecal $\mathrm{pH}$, copro-culture, and urine samples are analyzed.

In this way, an anti-oxidant and immune-stimulating action is carried on, and the effectiveness of some bacteria gets reduced (e.g. Salmonella, Clostridia, Lawsonia, Brachispira).

As for the delivery of ozone in the air, the concentration is about $0.1-0.2 \mathrm{ppm}$, in this case the main action carried out by ozone is to prevent the transmission of genes via aerogenic (Prrss, Mycoplasma, Influenza, Actinobacillus, and Streptococci).

Water was sampled and analyzed for the presence of the bacteriological load and the concentration of bacteria. Air was sampled by means of an "aerobiocollector", with a sampling of a given volume of air repeated over time. The air was vacuumed in by means of a fan and pushed against a filter, which eliminated impurities, but not bacteria. At this point, the forced air flow was directed on a surface consisting of agar, a gelatinous material capable of capturing bacteria, as well as providing them with a culture medium, allowing the subsequent analysis and enumeration of colony-forming units, after incubation. Foods were analyzed by means of direct count of microbial population and their viability, again through repeated sampling.

Specifically, with the use of ozone, it has been possible to drastically lower the level of microbial load present in the water (about $1.4 \mathrm{log}$ ), in the air (about $0.2 \mathrm{log}$ ) and in the food for animals (on average, $0.5 \mathrm{log}$ ), limiting the risk of infections.

The main outcome was the possibility of reducing, by $95 \%$, the other (pharmaceutical) antibacterial agents used (Figure 1), while the use of other disinfectants was reduced to almost zero. The immune system of the animals is strengthened (mortality decreased by $2 \%$ ); even in the few cases where the use of antibiotics is still necessary, these are associated with natural remedies mainly based on ozone, thus obtaining a 50\% decrease in the duration of infectious diseases. As mentioned, from the beginning of 2014 to 2016 and early 2017, as represented in Figure 1, there has been a convincing contraction in treatments with traditional, pharmaceutical antibiotics, along with consequent increment in phyto-therapy and homeopathy, which have also allowed constantly lowering (to almost zero level) other pharmaceutical drugs, such as disinfectants and acids (for the gastroenteric system). Since March 2017, this figure has not diminished any further, meaning that this is possibly the minimum optimal use of drugs, balanced by the use of ozone along with phyto-therapeutics.

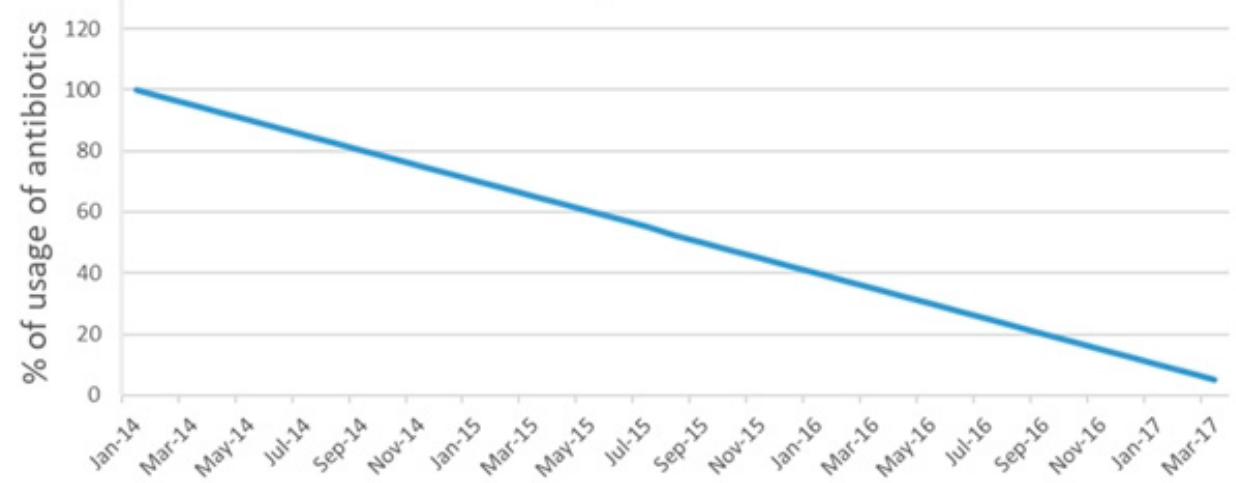

Figure 1. The linear decreasing of antibiotics usage in the pilot swine farm, since January 2014.

With 100 being the level of pre-2014 antibiotics usage, this level was reduced to about 5 during 2017 (it was about linearly decreasing in between, while, currently, this figure is stable).

From a pharmaco-economic point of view, the treatment based on ozone can be directly compared with the use of traditional drugs [139]. However, the ozone produced has also been used as a disinfectant in areas other than pure administration to animals, hence reducing other expenses. In general, the owner of the pilot farm estimates the savings to be about $€ 7-9$ per animal, in the three and half years that ozone has been used in the farm (about $€ 55,000-65,000$ in total). In Table 1, years 2014 and 2017 are considered, for a comparison (data from the pilot farm). 
Table 1. Comparison of costs in two different years (2014 and 2017). In 2014, in the pilot farm the usage of antibiotics and other pharmaceutical drugs had already been reduced, but only in 2017 (and on) ozone based treatments showed an optimal balance, which is now considered as steady.

\begin{tabular}{lcc}
\hline & $\mathbf{2 0 1 4}$ & $\mathbf{2 0 1 7}$ \\
\hline Traditional pharmaceutical drugs (antibiotics, disinfectants, ... ) & $€ 35,000$ & $€ 6000$ \\
Phytotherapies/homeopaths & $€ 19,000$ & $€ 41,000$ \\
Branchispira and chloristride control acids & $€ 66,000$ & - \\
Ten-year amortization of ozone plant & - & $€ 9000$ \\
Electrical costs of ozone plant & - & $€ 4000$ \\
Other maintenance costs & & $€ 2500$ \\
\hline Total & $\mathbf{€ 1 2 0 , 0 0 0}$ & $\mathbf{€ 6 2 , 5 0 0}$ \\
\hline
\end{tabular}

Another important factor is the increase in the number of pigs recorded from 2014 to 2015, which went from 5000 to 6500 (they are at about 7000 today). The interesting thing is that this increase in livestock does not affect the performance of ozone on animals, which over the years has remained about the same (as to cost and usage), hence potentially further increasing the savings per animal, up to a certain limit.

All this contributes to an improvement in the health of the animal, even reducing mortality by about $1 \%$, while keeping all the other factors at a steady state (e.g., the overall production of ham).

Obviously, these data are specific and referred to the pilot swine farm analyzed within the present study; results could vary in other contexts, with other animals or according to the size of the livestock.

The benefits for the consumer are present (mainly, a reduction in the risk of antibiotic resistance) and can be added to those for the environment (less dispersion of antibiotics). According to what has been derived from the analysis on the pilot farm, an economic sustainability can therefore also be glimpsed, which could be further increased if it is possible to create antibiotic-free supply chains that also cover aspects relating to animal feed and the treatment of food products.

If developed in larger scale, the use of ozone instead of antibiotics in animal farming could eventually lead to a decrease in antibiotic resistance (or, at least, could limit the existing phenomenon), also thanks to a lower dispersion of antibiotics concentrated in the water. At the same time, it would limit the use and dispersion of acids, disinfectants at the end of the cycle, anti-inflammatories towards the groundwater, with an overall benefit for the environment and, particularly, for the sea.

The spread and use of this plant are still very limited: there are only about a dozen farms in Europe that fully use this equipment.

\section{Conclusions}

An extensive and interdisciplinary literature review was carried out, with the aim to investigate the possible uses of synthetically produced ozone in several fields and to investigate the effectiveness of this treatment as an alternative to other ones, more conventional and widespread, usually based on pharmaceutical drugs and products. Along with environmental sustainability, also economic sustainability is constantly investigated.

The first interesting outcome is the versatility of this substance, which can be used as a natural method for the disinfection and purification of wastewater, as well as drinking water, but also in medicine, agriculture and livestock breeding. The literature examined in this research reports very interesting data on the effectiveness of such treatment, especially for the antibacterial and disinfectant action of ozone. In particular, the possibility of using ozone as an alternative to certain antibiotic products is of relevant importance, thus ensuring that the phenomenon of antibiotic resistance is less effective over time.

From these aspects, we can infer the potential environmental sustainability of ozone as a treatment.

From the point of view of private companies using ozone as a process innovation, it is important to also assess the economic and financial sustainability. With this aim, a pharmaco-economic approach 
can be pursued $[139,140]$, comparing the specific costs arising from the use of ozone in a given area with the costs arising from other alternative methods. For this purpose, in this paper, a case study on animal husbandry is presented. A swine farm in Northern Italy was analyzed as a pilot case, providing data and results from the protracted use over the years (since 2014) of methodologies based on ozone. From this analysis, the excellent performance of ozone-based treatments can be inferred, which even slightly reduced livestock mortality (about $2 \%$ ) and allowed greatly reducing the amount of antibiotics and pharmaceutical disinfectants used (by $95 \%$, while currently the figure is not changing anymore, having reached an optimal balance). As a result, these substances are less dispersed in the environment (e.g., in wastewater) and, above all, animals absorb fewer drugs. Considering the costs, the initial investment is significant, but it can be quickly amortized, considering a significant saving induced by the reduction of other substances. As to the analyzed pilot farm, already in the second year, the enterprise absorbed the initial investment carried out to purchase the ozone producing plant.

Along with the straightforward considerations about financial sustainability, also some managerial insights can be inferred. In particular, the use of ozone, as a natural substance, instead of other pharmaceutical and artificial drugs, especially if openly declared, can become a driver for differentiation strategy. The interest of companies towards themes of corporate social responsibility [141] (e.g., environment and community oriented activities) often leads to positive effects in terms of corporate reputation [142].

The main limitation of the present study is that the specific use case cannot be considered a generalized one. Further studies will have to consider other similar use cases to enlarge the studied sample. Besides, the same considerations will have to be carried out in other fields (e.g., medical science and agriculture).

Author Contributions: Both authors contributed to the conception of the work and to the research at the base of it. The article was written by M.R., who must therefore be considered as the main author. L.V. contributed with medical-scientific consultancy for the parts in which technical data are reported, for those specific sectors.

Funding: This research received no external funding.

Acknowledgments: The authors would like to gratefully acknowledge the ongoing scientific support of Marianno Franzini and the SIOOT (Italian Scientific Society of Oxygen-Ozone Therapy). They also wish to acknowledge the role of Garbelli, owner of the pilot farm, in making his data available to them and in replying to their questions.

Conflicts of Interest: The authors declare no conflict of interest.

\section{References}

1. Doppelt, B. Leading Change toward Sustainability: A Change-Management Guide for Business, Government and Civil Society; Routledge: Abingdon-on-Thames, UK, 2017.

2. Benn, S.; Edwards, M.; Williams, T. Organizational Change for Corporate Sustainability; Routledge: Abingdon-on-Thames, UK, 2014.

3. Smith, H.; Fingar, P. Business Process Management: The Third Wave; Meghan-Kiffer Press: Tampa, FL, USA, 2003; Volume 1.

4. Schaltegger, S.; Wagner, M. Sustainable entrepreneurship and sustainability innovation: Categories and interactions. Bus. Strategy Environ. 2011, 20, 222-237. [CrossRef]

5. Dangelico, R.M.; Pujari, D. Mainstreaming green product innovation: Why and how companies integrate environmental sustainability. J. Bus. Ethics 2010, 95, 471-486. [CrossRef]

6. Mahmoud, A.E.D.; Stolle, A.; Stelter, M. Sustainable synthesis of high-surface-area graphite oxide via dry ball milling. ACS Sustain. Chem. Eng. 2018, 6, 6358-6369. [CrossRef]

7. Millar, C.; Hind, P.; Magala, S. Sustainability and the need for change: Organisational change and transformational vision. J. Organ. Chang. Manag. 2012, 25, 489-500. [CrossRef]

8. Bocci, V. How Does Ozone Act? How and Why Can We Avoid Ozone Toxicity? Springer: Berlin/Heidelberg, Germany, 2005.

9. Seidler, V.; Linetskiy, I.; Hubálková, H.; Stankova, H.; Smucler, R.; Mazánek, J. Ozone and its usage in general medicine and dentistry. A review article. Prague Med. Rep. 2008, 109, 5-13. [PubMed] 
10. Eliasson, B.; Hirth, M.; Kogelschatz, U. Ozone synthesis from oxygen in dielectric barrier discharges. J. Phys. Appl. Phys. 1987, 20, 1421. [CrossRef]

11. Garamoon, A.A.; Elakshar, F.F.; Nossair, A.M.; Kotp, E.F. Experimental study of ozone synthesis. Plasma Sources Sci. Technol. 2002, 11, 254. [CrossRef]

12. Ma, H.; Qiu, Y. A study of ozone synthesis in coaxial cylinder pulse streamer corona discharge reactors. Ozone Sci. Eng. 2003, 25, 127-135. [CrossRef]

13. Pietsch, G.J.; Gibalov, V.I. Dielectric barrier discharges and ozone synthesis. Pure Appl. Chem. 1998, 70, 1169-1174. [CrossRef]

14. Bojkov, R.D. International Ozone Commission: History and Activities; IAMAS Publication Series: Bavaria, Germany, 2012.

15. Bojkov, R.D. Surface ozone during the second half of the nineteenth century. J. Clim. Appl. Meteorol. 1986, 25, 343-352. [CrossRef]

16. Rubin, M.B. The history of ozone. The Schönbein period, 1839-1868. Bull. Hist. Chem. 2001, 26, 40-56.

17. Braslavsky, S.E.; Rubin, M.B. The history of ozone Part VIII. Photochemical formation of ozone. Photochem. Photobiol. Sci. 2011, 10, 1515-1520. [CrossRef] [PubMed]

18. Rubin, M.B. The History of Ozone. Part III: CD Harries and the Introduction of Ozone into Organic Chemistry. Helv. Chim. Acta 2003, 86, 930-940. [CrossRef]

19. Bocci, V. Biological and clinical effects of ozone. Has ozone therapy a future in medicine? Br. J. Biomed. Sci. $1999,56,270$.

20. Kowalski, W.J.; Bahnfleth, W.P.; Whittam, T.S. Bactericidal effects of high airborne ozone concentrations on Escherichia coli and Staphylococcus aureus. Ozone Sci. Eng. 1998. [CrossRef]

21. Moore, G.; Griffith, C.; Peters, A. Bactericidal properties of ozone and its potential application as a terminal disinfectant. J. Food Prot. 2000, 63, 1100-1106. [CrossRef]

22. Blair, J.M.; Webber, M.A.; Baylay, A.J.; Ogbolu, D.O.; Piddock, L.J. Molecular mechanisms of antibiotic resistance. Nat. Rev. Microbiol. 2015, 13, 42. [CrossRef]

23. Li, X.-Z.; Plésiat, P.; Nikaido, H. The challenge of efflux-mediated antibiotic resistance in Gram-negative bacteria. Clin. Microbiol. Rev. 2015, 28, 337-418. [CrossRef]

24. Ventola, C.L. The antibiotic resistance crisis: Part 1: Causes and threats. Pharm. Ther. 2015, 40, 277.

25. Loeb, B.L. Ozone: Science \& Engineering: Thirty-three years and growing. Ozone Sci. Eng. 2011, 33, 329-342.

26. Von Gunten, U. The basics of oxidants in water treatment. Part B: Ozone reactions. Water Sci. Technol. 2007, 55. [CrossRef]

27. Loeb, B.L.; Thompson, C.M.; Drago, J.; Takahara, H.; Baig, S. Worldwide ozone capacity for treatment of drinking water and wastewater: A review. Ozone Sci. Eng. 2012, 34, 64-77. [CrossRef]

28. Glaze, W.H. Drinking-water treatment with ozone. Environ. Sci. Technol. 1987, 21, 224-230. [CrossRef]

29. Rice, R.G.; Robson, C.M.; Miller, G.W.; Hill, A.G. Uses of ozone in drinking water treatment. J.-Am. Water Works Assoc. 1981, 73, 44-57. [CrossRef]

30. Glaze, W.H.; Kang, J.-W.; Chapin, D.H. The chemistry of water treatment processes involving ozone, hydrogen peroxide and ultraviolet radiation. Ozone Sci. Eng. 1987. [CrossRef]

31. Ciambrone, D.F. Ozone Oxidation of Waste Water. U.S. Patent 4,007,118, 8 February 1977.

32. Gottschalk, C.; Libra, J.A.; Saupe, A. Ozonation of Water and Waste Water: A Practical Guide to Understanding Ozone and Its Applications; John Wiley \& Sons: Hoboken, NJ, USA, 2009.

33. Fiessinger, F.; Richard, Y.; Montiel, A.; Musquere, P. Advantages and disadvantages of chemical oxidation and disinfection by ozone and chlorine dioxide. Sci. Total Environ. 1981, 18, 245-261. [CrossRef]

34. Haag, W.R.; Hoigné, J. Ozonation of water containing chlorine or chloramines. Reaction products and kinetics. Water Res. 1983, 17, 1397-1402. [CrossRef]

35. Palermi, S.; Pitari, G.; Visconti, G. Ozone response to a CO2 doubling: Results from a stratospheric circulation model with heterogeneous chemistry. J. Geophys. Res.: Atmos. 1992, 97, 5953-5962.

36. Pelletier, N. Environmental performance in the US broiler poultry sector: Life cycle energy use and greenhouse gas, ozone depleting, acidifying and eutrophying emissions. Agric. Syst. 2008, 98, 67-73. [CrossRef]

37. Pascual, A.; Llorca, I.; Canut, A. Use of ozone in food industries for reducing the environmental impact of cleaning and disinfection activities. Trends Food Sci. Technol. 2007, 18, S29-S35. [CrossRef]

38. Bott, T.R. Ozone as a disinfectant in process plant. Food Control 1991, 2, 45-49. [CrossRef] 
39. Remondino, M. The use of ozone as a driver for economic and environmental sustainable development. Ozone Ther. 2018, 3. [CrossRef]

40. Czekalski, N.; Imminger, S.; Salhi, E.; Veljkovic, M.; Kleffel, K.; Drissner, D.; Hammes, F.; Bürgmann, H.; Von Gunten, U. Inactivation of antibiotic resistant bacteria and resistance genes by ozone: From laboratory experiments to full-scale wastewater treatment. Environ. Sci. Technol. 2016, 50, 11862-11871. [CrossRef] [PubMed]

41. Selma, M.V.; Allende, A.; López-Gálvez, F.; Conesa, M.A.; Gil, M.I. Disinfection potential of ozone, ultraviolet-C and their combination in wash water for the fresh-cut vegetable industry. Food Microbiol. 2008, 25, 809-814. [CrossRef] [PubMed]

42. Volk, C.; Roche, P.; Joret, J.-C.; Paillard, H. Comparison of the effect of ozone, ozone-hydrogen peroxide system and catalytic ozone on the biodegradable organic matter of a fulvic acid solution. Water Res. 1997, 31, 650-656. [CrossRef]

43. Volk, C.; Renner, C.; Roche, P.; Paillard, H.; Joret, J.C. Effects of ozone on the production of biodegradable dissolved organic carbon (BDOC) during water treatment. Ozone Sci. Eng. 1993, 15, 389-404. [CrossRef]

44. Bablon, G.; Bellamy, W.D.; Billen, G.; Bourbigot, M.-M.; Daniel, B.; Erb, F.; Gomella, C.; Gordon, G.; Hartemann, P.; Joret, J.C. Practical application of ozone: Principles and case studies. Ozone Water Treat. Appl. Eng. 1991, xvii, 569.

45. McDonnell, G.; Russell, A.D. Antiseptics and disinfectants: Activity, action, and resistance. Clin. Microbiol. Rev. 1999, 12, 147-179. [CrossRef]

46. Mahfoudh, A.; Barbeau, J.; Moisan, M.; Leduc, A.; Séguin, J. Biocidal action of ozone-treated polystyrene surfaces on vegetative and sporulated bacteria. Appl. Surf. Sci. 2010, 256, 3063-3072. [CrossRef]

47. Elford, W.J.; van den Ende, J. An investigation of the merits of ozone as an aerial disinfectant. Epidemiol. Infect. 1942, 42, 240-265. [CrossRef]

48. Keutgen, A.J.; Pawelzik, E. Influence of pre-harvest ozone exposure on quality of strawberry fruit under simulated retail conditions. Postharvest Biol. Technol. 2008, 49, 10-18. [CrossRef]

49. Loreto, F.; Mannozzi, M.; Maris, C.; Nascetti, P.; Ferranti, F.; Pasqualini, S. Ozone quenching properties of isoprene and its antioxidant role in leaves. Plant Physiol. 2001, 126, 993-1000. [CrossRef] [PubMed]

50. Eick, S.; Tigan, M.; Sculean, A. Effect of ozone on periodontopathogenic species-An in vitro study. Clin. Oral Investig. 2012, 16, 537-544. [CrossRef]

51. Lee, J.; Deininger, R.A. Survival of bacteria after ozonation. Ozone Sci. Eng. 2000. [CrossRef]

52. Von Gunten, U. Ozonation of drinking water: Part I. Oxidation kinetics and product formation. Water Res. 2003, 37, 1443-1467. [CrossRef]

53. Boorman, G.A. Drinking water disinfection byproducts: Review and approach to toxicity evaluation. Environ. Health Perspect. 1999, 107, 207. [PubMed]

54. Plewa, M.J.; Wagner, E.D.; Jazwierska, P.; Richardson, S.D.; Chen, P.H.; McKague, A.B. Halonitromethane drinking water disinfection byproducts: Chemical characterization and mammalian cell cytotoxicity and genotoxicity. Environ. Sci. Technol. 2004, 38, 62-68. [CrossRef] [PubMed]

55. Hei, R.D.; Guange-jong, J.W.; Cords, B.R.; Lokkesmoe, K.D. Potentiated Aqueous Ozone Cleaning and Sanitizing Composition for Removal of a Contaminating Soil from A surface. U.S. Patent US5567444A, 22 October 1996.

56. Mallmann, W.L.; Kain, C.H.; Schaefer, R.J. Apparatus and Method for Sanitizing. U.S. Patent US2388753A, 13 November 1945.

57. Blanc, D.S.; Carrara, P.; Zanetti, G.; Francioli, P. Water disinfection with ozone, copper and silver ions, and temperature increase to control Legionella: Seven years of experience in a university teaching hospital. J. Hosp. Infect. 2005, 60, 69-72. [CrossRef] [PubMed]

58. Edelstein, P.H.; Whittaker, R.E.; Kreiling, R.L.; Howell, C.L. Efficacy of ozone in eradication of Legionella pneumophila from hospital plumbing fixtures. Appl. Environ. Microbiol. 1982, 44, 1330-1333. [PubMed]

59. Brûlet, A.; Nicolle, M.-C.; Giard, M.; Nicolini, F.-E.; Michallet, M.; Jarraud, S.; Etienne, J.; Vanhems, P. Fatal nosocomial Legionella pneumophila infection due to exposure to contaminated water from a washbasin in a hematology unit. Infect. Control Hosp. Epidemiol. 2008, 29, 1091-1093. [CrossRef] [PubMed]

60. Woo, A.H.; Victor, L.Y.; Goetz, A. Potential in-hospital modes of transmission of Legionella pneumophila. Demonstration experiments for dissemination by showers, humidifiers, and rinsing of ventilation bag apparatus. Am. J. Med. 1986, 80, 567-573. [CrossRef] 
61. Feng, L.; Jiang, T.; Wang, Y.; Li, J. Effects of tea polyphenol coating combined with ozone water washing on the storage quality of black sea bream (Sparus macrocephalus). Food Chem. 2012, 135, 2915-2921. [CrossRef]

62. Kim, J.-G.; Yousef, A.E.; Dave, S. Application of ozone for enhancing the microbiological safety and quality of foods: A review. J. Food Prot. 1999, 62, 1071-1087. [CrossRef] [PubMed]

63. Ölmez, H.; Kretzschmar, U. Potential alternative disinfection methods for organic fresh-cut industry for minimizing water consumption and environmental impact. LWT-Food Sci. Technol. 2009, 42, 686-693. [CrossRef]

64. Bucks, D.A.; Nakayama, F.S.; Gilbert, R.G. Trickle irrigation water quality and preventive maintenance. Agric. Water Manag. 1979, 2, 149-162. [CrossRef]

65. Newman, S.E. Disinfecting irrigation water for disease management. In Proceedings of the 20th Annual Conference on Pest Management on Ornamentals, San Jose, CA, USA, 20-22 February 2004; pp. 20-22.

66. Steele, M.; Odumeru, J. Irrigation water as source of foodborne pathogens on fruit and vegetables. J. Food Prot. 2004, 67, 2839-2849. [CrossRef]

67. Lagerkvist, B.J.; Bernard, A.; Blomberg, A.; Bergstrom, E.; Forsberg, B.; Holmstrom, K.; Karp, K.; Lundstrom, N.-G.; Segerstedt, B.; Svensson, M. Pulmonary epithelial integrity in children: Relationship to ambient ozone exposure and swimming pool attendance. Environ. Health Perspect. 2004, 112, 1768. [CrossRef] [PubMed]

68. Zwiener, C.; Richardson, S.D.; De Marini, D.M.; Grummt, T.; Glauner, T.; Frimmel, F.H. Drowning in disinfection byproducts? Assessing swimming pool water. Environ. Sci. Technol. 2007, 41, 363-372. [CrossRef]

69. Boeniger, M.F. Use of ozone generating devices to improve indoor air quality. Am. Ind. Hyg. Assoc. J. 1995, 56, 590-598. [CrossRef]

70. Clavo, B.; Pérez, J.L.; López, L.; Suárez, G.; Lloret, M.; Rodríguez, V.; Macías, D.; Santana, M.; Morera, J.; Fiuza, D. Effect of ozone therapy on muscle oxygenation. J. Altern. Complement. Med. 2003, 9, 251-256. [CrossRef]

71. Bocci, V.; Di Paolo, N. Oxygen-ozone therapy in medicine: An update. Blood Purif. 2009, 28, 373-376. [CrossRef] [PubMed]

72. Buckley, R.D.; Hackney, J.D.; Clark, K.; Posin, C. Ozone and human blood. Arch. Environ. Health Int. J. 1975, 30, 40-43. [CrossRef]

73. Wong, C.-M.; Ma, S.; Hedley, A.J.; Lam, T.-H. Does ozone have any effect on daily hospital admissions for circulatory diseases? J. Epidemiol. Community Health 1999, 53, 580. [CrossRef] [PubMed]

74. Valacchi, G.; Fortino, V.; Bocci, V. The dual action of ozone on the skin. Br. J. Dermatol. 2005, 153, 1096-1100. [CrossRef] [PubMed]

75. Jekel, M.R. Flocculation effects of ozone. Ozone Sci. Eng. 1994, 16, 55-66. [CrossRef]

76. Jun, Y.; Lu, S.; Ding, Y. Treatment of Simulated Dyeing Wastewater by Modified Red Mud Flocculation-Ozone Oxidation Process. Environ. Prot. Chem. Ind. 2010, 4. [CrossRef]

77. Sliter, J.T. Ozone: An alternative to chlorine? J. Water Pollut. Control Fed. 1974, 4-6.

78. Kim, S.; Aga, D.S. Potential ecological and human health impacts of antibiotics and antibiotic-resistant bacteria from wastewater treatment plants. J. Toxicol. Environ. Health Part B 2007, 10, 559-573. [CrossRef]

79. Baquero, F.; Martínez, J.-L.; Cantón, R. Antibiotics and antibiotic resistance in water environments. Curr. Opin. Biotechnol. 2008, 19, 260-265. [CrossRef]

80. Farooq, S.; Akhlaque, S. Comparative response of mixed cultures of bacteria and virus to ozonation. Water Res. 1983, 17, 809-812. [CrossRef]

81. Reckhow, D.A.; Knocke, W.R.; Kearney, M.J.; Parks, C.A. Oxidation of iron and manganese by ozone. Ozone Sci. Eng. 1991, 13, 675-695. [CrossRef]

82. Giunta, R.; Coppola, A.; Luongo, C.; Sammartino, A.; Guastafierro, S.; Grassia, A.; Giunta, L.; Mascolo, L.; Tirelli, A.; Coppola, L. Ozonized autohemotransfusion improves hemorheological parameters and oxygen delivery to tissues in patients with peripheral occlusive arterial disease. Ann. Hematol. 2001, 80, 745-748. [CrossRef] [PubMed]

83. Häußler, U. Effect of Ozone/Oxygen-Pneumoperitoneum on Tumour Growth and Metastatic Spread of the Rabbit VX2 Head and Neck Cancer Model. Philipps-Universität Marburg: Marburg, Germany, 2009. Available online: http:/ / archiv.ub.uni-marburg.de/diss/z2009/0028 (accessed on 14 December 2018). 
84. Valdenassi, L.; Franzini, M.; Garbelli, P.; Camolese, M. Oxygen-ozone activity in making factory farms antibiotic-free for prevention of antibiotic resistance. Ozone Ther. 2016, 1, 42-44. [CrossRef]

85. Tacconelli, E.; Carrara, E.; Savoldi, A.; Harbarth, S.; Mendelson, M.; Monnet, D.L.; Pulcini, C.; Kahlmeter, G.; Kluytmans, J.; Carmeli, Y. Discovery, research, and development of new antibiotics: The WHO priority list of antibiotic-resistant bacteria and tuberculosis. Lancet Infect. Dis. 2018, 18, 318-327. [CrossRef]

86. Franzini, M.; Valdenassi, L.; Ionita, G. First evaluations of oxygen-ozone therapy in antibiotic-resistant infections. Ozone Ther. 2016, 1, 5-7. [CrossRef]

87. Laxminarayan, R.; Amábile-Cuevas, C.F.; Cars, O.; Evans, T.; Heymann, D.L.; Hoffman, S.; Holmes, A.; Mendelson, M.; Sridhar, D.; Woolhouse, M. UN High-Level Meeting on antimicrobials—What do we need? Lancet 2016, 388, 218-220. [CrossRef]

88. Jasovskỳ, D.; Littmann, J.; Zorzet, A.; Cars, O. Antimicrobial resistance-A threat to the world's sustainable development. Upsal. J. Med. Sci. 2016, 121, 159-164. [CrossRef]

89. Liu, Y.-Y.; Wang, Y.; Walsh, T.R.; Yi, L.-X.; Zhang, R.; Spencer, J.; Doi, Y.; Tian, G.; Dong, B.; Huang, X. Emergence of plasmid-mediated colistin resistance mechanism MCR-1 in animals and human beings in China: A microbiological and molecular biological study. Lancet Infect. Dis. 2016, 16, 161-168. [CrossRef]

90. Skov, R.L.; Monnet, D.L. Plasmid-mediated colistin resistance (mcr-1 gene): Three months later, the story unfolds. Eurosurveillance 2016, 21, 30155. [CrossRef] [PubMed]

91. Rice, L.B. Federal Funding for the Study of Antimicrobial Resistance in Nosocomial Pathogens: No ESKAPE. J. Infect. Dis. 2008, 197, 1079-1081. [CrossRef] [PubMed]

92. Roca, I.; Akova, M.; Baquero, F.; Carlet, J.; Cavaleri, M.; Coenen, S.; Cohen, J.; Findlay, D.; Gyssens, I.; Heure, O.E. The global threat of antimicrobial resistance: Science for intervention. New Microbes New Infect. 2015, 6, 22-29. [CrossRef] [PubMed]

93. Hoagland, D.T.; Liu, J.; Lee, R.B.; Lee, R.E. New agents for the treatment of drug-resistant Mycobacterium tuberculosis. Adv. Drug Deliv. Rev. 2016, 102, 55-72. [CrossRef] [PubMed]

94. Zaman, S.B.; Hussain, M.A.; Nye, R.; Mehta, V.; Mamun, K.T.; Hossain, N. A review on antibiotic resistance: Alarm bells are ringing. Cureus 2017, 9. [CrossRef] [PubMed]

95. Qin, S.; Cheng, L.; Selorm, A.L.; Yuan, F. An Overview of Ozone Research. J. Adv. Oxid. Technol. 2018, 21, 297-302. [CrossRef]

96. Feng, L.; Zhang, K.; Gao, M.; Shi, C.; Ge, C.; Qu, D.; Zhu, J.; Shi, Y.; Han, J. Inactivation of Vibrio parahaemolyticus by Aqueous Ozone. J. Microbiol. Biotechnol. 2018, 28, 1233-1246. [PubMed]

97. NULL Franzini: "L'ozono può Sconfiggere i Superbatteri"; ZENIT Italia: San Cesario sul Panaro, Italy, 2016.

98. Wolf, C.; von Gunten, U.; Kohn, T. Virus inactivation by ozone: Kinetics and influence of water quality parameters. In Proceedings of the IWA International Symposium on Health-Related Water Microbiology, Chapel Hill, NC, USA, 15-19 May 2017.

99. Marcelino, R.B.; Leão, M.M.; Lago, R.M.; Amorim, C.C. Multistage ozone and biological treatment system for real wastewater containing antibiotics. J. Environ. Manag. 2017, 195, 110-116. [CrossRef] [PubMed]

100. Sacco, G.; Campus, G. The treatment of periodontal disease using local oxygen-ozone. Ozone Ther. 2017, 1, 45-52. [CrossRef]

101. Godfray, H.C.J.; Beddington, J.R.; Crute, I.R.; Haddad, L.; Lawrence, D.; Muir, J.F.; Pretty, J.; Robinson, S.; Thomas, S.M.; Toulmin, C. Food security: The challenge of feeding 9 billion people. Science 2010, 327, 812-818. [CrossRef] [PubMed]

102. Winter, C.K.; Davis, S.F. Organic foods. J. Food Sci. 2006, 71, R117-R124. [CrossRef]

103. Mann, R.M.; Hyne, R.V.; Choung, C.B.; Wilson, S.P. Amphibians and agricultural chemicals: Review of the risks in a complex environment. Environ. Pollut. 2009, 157, 2903-2927. [CrossRef]

104. Weil, C.S.; McCollister, D.D. Safety evaluation of chemicals, relationship between short-and long-term feeding studies in designing an effective toxicity test. J. Agric. Food Chem. 1963, 11, 486-491. [CrossRef]

105. Ecobichon, D.J. Pesticide use in developing countries. Toxicology 2001, 160, 27-33. [CrossRef]

106. Pope, C.N. Organophosphorus pesticides: Do they all have the same mechanism of toxicity? J. Toxicol. Environ. Health B Crit. Rev. 1999, 2, 161-181. [CrossRef] [PubMed]

107. Vozmilov, A.G.; Ilimbetov, R.Y.; Astafev, D.V. The usage of ozone in agriculture technological processes. In Proceedings of the 2016 2nd International Conference on Industrial Engineering, Applications and Manufacturing (ICIEAM), Chelyabinsk, Russia, 19-20 May 2016; pp. 1-4. 
108. Nürnberger, T.; Brunner, F. Innate immunity in plants and animals: Emerging parallels between the recognition of general elicitors and pathogen-associated molecular patterns. Curr. Opin. Plant Biol. 2002, 5, 318-324. [CrossRef]

109. Nicol, J.M.; Turner, S.J.; Coyne, D.L.; Den Nijs, L.; Hockland, S.; Maafi, Z.T. Current nematode threats to world agriculture. In Genomics and Molecular Genetics of Plant-Nematode Interactions; Springer: Berlin/Heidelberg, Germany, 2011; pp. 21-43.

110. Msayleb, N.; Ibrahim, S. Treatment of nematodes with ozone gas: A sustainable alternative to nematicides. Phys. Procedia 2011, 21, 187-192. [CrossRef]

111. Margni, M.; Rossier, D.; Crettaz, P.; Jolliet, O. Life cycle impact assessment of pesticides on human health and ecosystems. Agric. Ecosyst. Environ. 2002, 93, 379-392. [CrossRef]

112. Lozowicka, B.; Jankowska, M.; Hrynko, I.; Kaczynski, P. Removal of 16 pesticide residues from strawberries by washing with tap and ozone water, ultrasonic cleaning and boiling. Environ. Monit. Assess. 2016, 188, 51. [CrossRef]

113. Khadre, M.A.; Yousef, A.E.; Kim, J.-G. Microbiological aspects of ozone applications in food: A review. J. Food Sci. 2001, 66, 1242-1252. [CrossRef]

114. Sopher, C.D.; Graham, D.M.; Rice, R.G.; Strasser, J.H. Studies on the use of ozone in production agriculture and food processing. In Proceedings of the International Ozone Association, Pan American Group, Raleigh-Durham, NC, USA, 18-22 May 2002; pp. 1-15.

115. Tai, P.L. Ozone Injection System for a Livestock Building. U.S. Patent US5983834A, 16 November 1999.

116. Mallakian, S.; Rezanezhad, R.; Jalali, M.; Ghobadi, F. The effect of ozone gas on destruction and detoxification of aflatoxin. Agric. Eng. Lett. 2017, 1, 9-16.

117. Correa, R. Method for Improving Conditions in a Poultry Grow out Facility Prior to Placing Chicks by Means of Ozone. U.S. Patent US20160015846A1, 21 January 2016.

118. Elliott, K.A.; Kenny, C.; Madan, J. A Global Treaty to Reduce Antimicrobial Use in Livestock; Center for Global Development: Washington, DC, USA, 2017.

119. Yanqiu, L.; Dongfeng, H.; Xingang, Y.; Xuejun, Y.; Liangxing, B.; Yong, X.; Meili, W.; Guodong, X.; Yongfu, Z.; Chunmei, L. Ozone Disinfection Test in Chicken House. Anim. Husb. Feed Sci. 2018, 10, 97-98.

120. Wolf, C.; von Gunten, U.; Kohn, T. Inactivation of enteric viruses by ozone. In Proceedings of the Gordon Research Seminar, Environmental Sciences Water: Opportunities for Aquatic Sciences to Impact a Changing World, Holderness, NH, USA, 22-27 June 2016.

121. Biswas, S.K.; Jana, C.; Chand, K.; Rehman, W.; Mondal, B. Detection of fowl poxvirus integrated with reticuloendotheliosis virus sequences from an outbreak in backyard chickens in India. Vet. Ital. 2011, 47, 147-153. [PubMed]

122. Tothill, I.E.; Turner, A.P.F. New developments and opportunities in the diagnosis of livestock diseases. Livest. Dis. Diagn. 1998, 21, 79-94.

123. Powell, A.; Chingombe, P.; Lupatsch, I.; Shields, R.J.; Lloyd, R. The effect of ozone on water quality and survival of turbot (Psetta maxima) maintained in a recirculating aquaculture system. Aquac. Eng. 2015, 64, 20-24. [CrossRef]

124. Guzel-Seydim, Z.B.; Greene, A.K.; Seydim, A.C. Use of ozone in the food industry. LWT-Food Sci. Technol. 2004, 37, 453-460. [CrossRef]

125. Burger, M.R. Air Purification Electrostatic Charcoal Filter and Method. U.S. Patent US4244710A, 13 January 1981.

126. Pichat, P.; Disdier, J.; Hoang-Van, C.; Mas, D.; Goutailler, G.; Gaysse, C. Purification/deodorization of indoor air and gaseous effluents by $\mathrm{TiO}_{2}$ photocatalysis. Catal. Today 2000, 63, 363-369. [CrossRef]

127. Babando, P. Ozone therapy in dentistry: Clinical experiences. Ozone Ther. 2017, 2. [CrossRef]

128. Almeida, A.; Cunha, Â.; Gomes, N.; Alves, E.; Costa, L.; Faustino, M.A. Phage therapy and photodynamic therapy: Low environmental impact approaches to inactivate microorganisms in fish farming plants. Mar. Drugs 2009, 7, 268-313. [CrossRef]

129. Forneris, G.; Bellardi, S.; Palmegiano, G.B.; Saroglia, M.; Sicuro, B.; Gasco, L.; Zoccarato, I. The use of ozone in trout hatchery to reduce saprolegniasis incidence. Aquaculture 2003, 221, 157-166. [CrossRef]

130. Crisinel, P.; Prost, L.; Bon, L. Method for Improving Conditions in Closed Circuit Fish Farming. U.S. Patent US6722314B1, 20 April 2004. 
131. Liltved, H.; Hektoen, H.; Efraimsen, H. Inactivation of bacterial and viral fish pathogens by ozonation or UV irradiation in water of different salinity. Aquac. Eng. 1995, 14, 107-122. [CrossRef]

132. Powell, A.; Scolding, J.W. Direct application of ozone in aquaculture systems. Rev. Aquac. 2018, 10, 424-438. [CrossRef]

133. DJuričić, D.; Valpotić, H.; Samardžija, M. Prophylaxis and therapeutic potential of ozone in buiatrics: Current knowledge. Anim. Reprod. Sci. 2015, 159, 1-7. [CrossRef] [PubMed]

134. Özlem Enginler, S.; Sabuncu, A.; Başaran Kahraman, B.; Koçak, Ö.; Yıldar, E.; Güzel, Ö. Comparison of intramammary ozone administration doses in dairy cows with clinical mastitis. Acta Sci. Vet. 2015, 43, 1260.

135. Soares, C.; Weber, A.; Moecke, E.S.; Reiter, M.G.; Scussel, V.M.; De Souza, C.K. Use of Ozone Gas as a Green Control Alternative to Beetles Alphitobius diaperinus (Panzer) Infestation in Aviary Bed Utilized in the Poultry Industry. Chem. Eng. Trans. 2018, 64, 589-594.

136. Zargaran, M.; Fatahinia, M.; Mahmoudabadi, A.Z. The efficacy of gaseous ozone against different forms of Candida albicans. Curr. Med. Mycol. 2017, 3, 26. [CrossRef] [PubMed]

137. Rajabi, O.; Sazgarnia, A.; Abbasi, F.; Layegh, P. The activity of ozonated olive oil against Leishmania major promastigotes. Iran. J. Basic Med. Sci. 2015, 18, 915.

138. Caplan, J.A. Therapeutic ozone agent and treatment. 2018. Available online: http:/ /www.freepatentsonline. com/y2016/0175353.html (accessed on 3 October 2018).

139. Remondino, M.; Valdenassi, L.; Franzini, M. Pharmacoeconomic analysis of ozone therapy supported by agent based process simulation and data mining. Ozone Ther. 2018, 3. [CrossRef]

140. Remondino, M.; Franzini, M. Pharmacoeconomics as a Management and Financial Strategy in Healthcare and Simulation as a Decision Making Tool for it: The Case of Ozone Therapy. Int. J. Simul. Syst. Sci. Technol. 2018, 19, 28.1-28.10. [CrossRef]

141. Carroll, A.B. The pyramid of corporate social responsibility: Toward the moral management of organizational stakeholders. Bus. Horiz. 1991, 34, 39-48. [CrossRef]

142. Khan, M.; Majid, A.; Yasir, M.; Arshad, M. Corporate social responsibility and corporate reputation: A case of cement industry in Pakistan. Interdiscip. J. Contemp. Res. Bus. 2013, 5, 843-857.

(C) 2018 by the authors. Licensee MDPI, Basel, Switzerland. This article is an open access article distributed under the terms and conditions of the Creative Commons Attribution (CC BY) license (http://creativecommons.org/licenses/by/4.0/). 